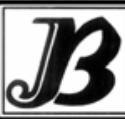

J. bio-sci. 18: $60-65,2010$

ISSN 1023-8654

http://www.banglajol.info/index.php/JBS/index

\title{
THE POPULATION GROWTH OF MACROBRACHIUM LAMARREI (H M EDWARDS) ON DIFFERENT CONDITIONS
}

\author{
Anjuman A Ara, M A Mannan and Selina Parween* \\ Department of Zoology, University of Rajshahi, Rajshahi-6205, Bangladesh
}

\begin{abstract}
Context: Bottom condition and aquatic plants of the water bodies play important roles on the population growth of Macrobrachium lamarrei.

Objective: To study the effects of different bottoms and aquatic vegetations on the population growth of Macrobrachium lamarei.

Materials and Methods: Brood stocks of $M$. lamarrei were maintained in mini ponds, and they were fed in $24 \mathrm{~h}$ with supplemental diets. For observing the effect of bottom condition on the prawn population three tanks (each 32"x36"x21"with a constant water depth of 16") were prepared: tank I, cemented bottom with no vegetation; tank II, muddy bottom and with water hyacinth and tank III, sandy-muddy bottom (2:1) with water hyacinth. To study the effect of aquatic plants on the population separate four tanks were prepared with sandy-muddy bottom (1:1) and subsequently with different vegetations. These were: tank I with Ipomea, tank II with Alternanthera, tank III with Eichornia, Ipomea, Alternanthera, Wolffia and Lemna, tank IV with Wolffia and Lemna. M. lamarrei of both sexes ( $\mathrm{N}=$ 40-55) were released in each tank depending on the experimental type. Number of prawns of different stages was counted after 3 and 6 months to determine the effect of bottom condition, and after 3, 69 and 12 months to record the effect of aquatic plants.

Results: M. lamarrei was found to prefer sandy-muddy bottom than cemented or muddy bottoms. The total population was recorded after six months as 760 (tank I), 1018 (tank II) and 1542 (tank III) where the initial number of released prawns was 55. Aquatic vegetations affected the population growthdifferently. After 12 months the total population was recorded as 2590 (tank I), 3416 (tank II), 1360 (tank III) and 1580 (tank IV). Population of M. lamarrei was maximum when Alternanthera (Santi sak) was present.

Conclusion: The results provide baseline information for establishing culture system for $M$. lamarrei and related smaller species of this genus simultaneously.
\end{abstract}

Keywords: Bottom condition, aquatic vegetation, population, Macrobrachium lamarrei.

\section{Introduction}

Macrobrachium lamarrei (H M Edwards) is abundantly distributed in the shallow water of beels and rivers throughout the year in the North-Western districts of Bangladesh (Ali et al. 1980, Kibria 1983, Parween et al. 1997). It is also reported from the freshwater and slightly saline zone of the estuaries of India (Rajyalakshmi, 1961). M. lamarrei also inhabits in ponds with abundant aquatic vegetation (Parween 1982). It is commonly known as "Gura Chingri".

For fruitful culture of aquatic species physical, chemical and biological parameters of the culture water should be in optimum. In ponds M. lamarrei can be cultured along with carps (Chawdhury 1970). Such parameters have been reported for culturing Macrobrachium rosenbergii (deMan), which are negligible for culturing $M$. lamarrei, Macrobrachium dayanum (Henderson), etc. These smaller species have markets for low income group of people, and play role in the food security through protein supply at low cost. To relax the catch pressure on the natural stocks of this species and associated other fish species, M. lamarrei can be cultured in small closed water bodies along with other fishes. The present work was aimed to find out the effect of different species of aquatic vegetations and bottom conditions on the production of $M$. lamarrei.

* Corresponding author E-mail: parween_s @yahoo.com 


\section{Materials and Methods}

Brood stocks of $M$. lamarrei were maintained in the Aqua-lab, Department of Zoology, University of Rajshahi. The berried females and the non-berried females and males were separately kept in earthen chari filling with pond water. The water was aerated continuously and placed under shade to acclimatize the condition for 3-4 days. These shrimps were then collected and released in the adjacent mini pond (size $80 \mathrm{~m}^{2}$ ). Supplementary feeds were provided once in 24 hours. Such stocking of $M$. lamarrei was continued for three weeks and then required number of $M$. lamarrei was collected at night, kept in aquarium containing pond water. The effects of bottom condition and vegetation on the population growth of $M$. lamarrei were observed.

Preparation of the experimental tank: The experiment was conducted in cemented tank (32" $\times 36 " \times 21 ")$ containing pond water of 16 "depth. Two weeks prior to the anticipation of the experiment the tanks were washed thoroughly and allowed to dry. After one week, the tanks were filled with water directly pumping from the large rearing pond of the Aqua-lab.

Tank type: For experiment 1 three types of tanks were selected. Tank I with cemented bottom and free of aquatic vegetation. Tank II with muddy bottom and water hyacinth was placed on the water surface. Tank III with sandy-muddy bottom with a ratio of 2:1 and water hyacinth was present.

For experiment separate two set of four tanks of the mentioned size were maintained, each having sandymuddy bottom (1:1). In tank I Ipomea (kalmi shak); tank II Alternanthera (santi shak); tank III Eichornia (water hyacinth), Ipomea, Alternanthera, Wolffia (topa pana) and Lemna (khudi pana) and tank IV, Wolffia and Lemna were placed on the water surface.

Stocking of the prawns: In experiment 1, 40 berried females and 15 adult males of M. lamarrei, were released in each of the tanks. At the time of stocking the total length and total body weight of the prawns were recorded. In the second set of tanks (experiment 2), 40 berried females were released after recording their total length and total body weight.

Harvest: In experiment 1 after three months an intermediate harvest was done. Number of the prawns were counted and weighed quickly, then transferred to their tanks immediately. The tanks were again filled with water. Final harvest had done after six months by complete draining off the tanks. Prawns remaining attached within the vegetation and in the mud were collected by hand. The number of the prawns was counted and weight of the total population was recorded. In the experiment 2 the shrimps of the tanks I, II, III, and IV were monitored regularly. After releasing the larvae all the spent females were removed carefully. Final harvest was done after 12 months. These experiments were carried during a period from August, 2001 to July, 2002. Both the experiments were replicated twice.

Statistical Analysis: Variation of productions in different tanks were tested by aanalysis of variance (ANOVA), and differences of means were tested by Tukey's Test (Tukey 1953). The tests were done by using the software Genstst 12.1.

\section{Results}

Effect of bottom condition: M. lamarrei were found to prefer sandy-muddy bottom than the muddy or cemented bottom (Table 1), and the presence of water hyacinth provided shade and shelter to the prawns, which positively helped the population growth. The total weight of the prawns was recorded after three months were 29.89, 37.25 and $54.65 \mathrm{~g}$ in tank I, II and III respectively (Table 1). The number of prawns was increased including the dead individuals, as 760 (tank I), 1018 (tank II) and 1542 (tank III). The increased population was formed by the juveniles (Table 1). The data also revealed that in the tank III, the juveniles were of maximum size in comparison with that of the other two tanks. However, after six months, the rate of population growth in all tanks was found to be reduced in terms of both number of individuals and total 
weight of the shrimps, though the number of prawns was maximum in tank III (Table 1) because the harvested prawns after three months, were not released in the tanks. From this experiment it is revealed that $M$. lamarrei thrives well in sandy-muddy soil in presence of aquatic vegetation. The population comprised both first time breeder females along with those females who breed earlier, unsexed juveniles and immature adults. Total number of progeny per female prawn was calculated as 185, 568 and 1065 after six months (Table 1). These results revealed that bottom conditions of the tanks were significantly correlated with the production of $M$. lamarrei $(F=119409.7, p<0.001)$; and according to Tukey's test the most effective bottom condition for better production of $M$. lamarrei was obtained in tankI >tank II >tank III.

Effect of vegetation type on hatching and development of $M$. lamarrei: In experiment 2, the effect of different species of aquatic plants on the growth and development of $M$. lamarrei was assessed after12 months. The data showed that the plant species had profound effect on the growth and development of the larvae, immature adult and juveniles of $M$. lamarrei (Table 2). After spawning of the parental prawns they were sieved out from the tanks after three months. The results showed that Alternanthera increased the survivability rate of the individuals after 9 months of rearing. In a one year period the maximum production of prawns (in number) and their metamorphosis was achieved in tank II then tank I > tank IV > tank III (Tukey's test). However, from $4^{\text {th }}$ to $6^{\text {th }}$ month, the number of juveniles decreased in tank I and tank II and remained constant in other two tanks; and by this time the juveniles formed adult stage (Table 2). As a result the juvenile population was declined after six months and the immature adults began to breed for the first time. After 12 months, the population became doubled. Statistically production of M. lamarrei differed significantly in all tanks $(F=11690, p<0.001)$.

Table 1. Effect of bottom condition of tank, vegetation, $\mathrm{pH}$ and water temperature on the population structure of $M$. lamarrei in six months period

\begin{tabular}{|c|c|c|c|}
\hline \multirow{2}{*}{ Parameters } & \multicolumn{3}{|c|}{ Population of $M$. lamarrei in different tanks } \\
\hline & Tank 1 & Tank 2 & Tank 3 \\
\hline Bottom condition & Cemented & Mud & Sand :Mud (2:1) \\
\hline Water area $(\mathrm{cm})(\mathrm{L} \times \mathrm{W} \times \mathrm{D})$ & $800 \times 900 \times 525$ & $800 \times 900 \times 525$ & $800 \times 900 \times 525$ \\
\hline Water level $(\mathrm{cm})$ & 400 & 400 & 400 \\
\hline Vegetation (Water hyacinth) & Absent & Present & Present \\
\hline $\mathrm{pH}$ (range) & $7.8-8.4$ & $7.9-8.6$ & $8.0-8.6$ \\
\hline Water temperature ${ }^{\circ} \mathrm{C}$ (range) & $22.5-29.7$ & $22.5-29.0$ & $22.5-29.5$ \\
\hline \multicolumn{4}{|l|}{ Release of prawn: September } \\
\hline Number of released & $\begin{array}{l}\text { BF } 40, \text { M } 15 \\
\text { Total } 55\end{array}$ & $\begin{array}{l}\text { BF } 40, \text { M } 15 \\
\text { Total } 55\end{array}$ & $\begin{array}{l}\text { BF } 40, \text { M } 15 \\
\quad \text { Total } 55\end{array}$ \\
\hline Total weight of $\mathrm{BF}(\mathrm{g})$ & 22.36 & 22.80 & 23.58 \\
\hline Total length (mm) (range) & $30-48$ & $30-48$ & $30-50$ \\
\hline \multicolumn{4}{|c|}{$1^{\text {st }}$ catch and release: December (3 months) } \\
\hline Number of prawn & $\begin{array}{r}\text { SF } 30, \text { M } 8, \text { J 705, } \\
\text { Total } 760\end{array}$ & $\begin{array}{c}\text { SF } 32, \text { M } 10, \text { J } 963, \text { D } 13 \\
\text { Total } 1018\end{array}$ & $\begin{array}{c}\text { SF } 36, \text { M } 11, \text { J } 1488, \quad \text { D } 8 \\
\text { Total } 1543\end{array}$ \\
\hline \multirow[t]{2}{*}{ Total weight of BF (g) } & A10.15 J19.74 & A 10.29 J 26.25 & A $12.99 \mathrm{~J} 41.66$ \\
\hline & Total 29.89 & Total 37.25 & Total 54.65 \\
\hline Total length $(\mathrm{mm})$ (range) & A $31-48.50, \mathrm{~J} 4-12$ & A $31.5-49, \mathrm{~J} 4-12$ & A $31.5-51.5, \mathrm{~J} 10-13$ \\
\hline \multicolumn{4}{|l|}{ Final harvest: March (6 months) } \\
\hline Number of prawns & $\begin{array}{c}\text { O9, BF7, SF4, M5, MA105, } \\
\text { J80, D10 } \\
\text { Total } 220\end{array}$ & $\begin{array}{l}\text { BF 14, SF10, M8, MA280, } \\
\text { J288, D10 }\end{array}$ & $\begin{array}{c}\text { BF18, Sf13, M8, MA560, J505, } \\
\text { D8 }\end{array}$ \\
\hline \multirow{2}{*}{ Total weight (g) } & A8.67, IA3.15, J 2.24 & A9.84, IM8.4, J 8.06 & A12.77, IM19.8, J14.14 \\
\hline & Total 14.06 & Total 26.3 & Total 43.71 \\
\hline \multirow{2}{*}{ Total length $(\mathrm{mm})$ (range) } & A $31-48.5$ & A $31-49$ & A $31-51.5$ \\
\hline & IM $19-24$, J $4-10$ & IM $20-26$, J $4-12$ & IM $21-27, \mathrm{~J} 4-11$ \\
\hline Total population per female & 185 (by No.) 4.62 (by wt.) & 568 (by No.) 14.2 (by wt.) & 1065 (by No.) 26.62 (by wt.) \\
\hline
\end{tabular}

Note: $\mathrm{BF}=$ Berried female, $\mathrm{SF}=$ Spent female, $\mathrm{M}=\mathrm{Male}, \mathrm{A}=$ Adult (unsexed), IM=Immature adult, $\mathrm{MA}=$ Mature adult, $\mathrm{J}=\mathrm{Juvenile}, \mathrm{D}=\mathrm{Dead}$. 
Table 2. Effect of soil and vegetation types on the population of $M$. lamarrei in 12 months period

\begin{tabular}{|c|c|c|c|c|}
\hline \multirow{2}{*}{ Parameters } & \multicolumn{4}{|c|}{ Population of $M$. lamarrei in different tanks } \\
\hline & Tank-1 & Tank-2 & Tank-3 & Tank-4 \\
\hline Soil type & Sandy:muddy (1:1) & Sandy:muddy (1:1) & Sandy:muddy (1:1) & Sandy:muddy (1:1) \\
\hline Water area $(\mathrm{cm})(\mathrm{L} \times \mathrm{W} \times \mathrm{D})$ & $800 \times 900 \times 525$ & $800 \times 900 \times 525$ & $800 \times 900 \times 525$ & $800 \times 900 \times 525$ \\
\hline Water level $(\mathrm{cm})$ & 400 & 400 & 400 & 400 \\
\hline Vegetatio & Ipomea & Alternanthera & $\begin{array}{l}\text { Ipomea, Alternanthera, } \\
\text { Eichhornia, Wolffia, Lemna }\end{array}$ & Wolffia, Lemna \\
\hline $\mathrm{pH}$ (range) & $7.8-8.4$ & $7.9-8.6$ & $8.0-8.6$ & $7.9-8.5$ \\
\hline \multicolumn{5}{|l|}{ Initial release: July } \\
\hline Number of prawn & BF 40 & BF 40 & BF 40 & BF 40 \\
\hline Total length (mm) (range) & $36-60$ & $36-59$ & $35-60$ & $35-61$ \\
\hline \multicolumn{5}{|l|}{ Catch after 3 months } \\
\hline Number of juveniles & 1105 & 1080 & 920 & 925 \\
\hline Total length (mm) (range) & $4-12$ & $4-12$ & $4-12$ & $4-12$ \\
\hline \multicolumn{5}{|l|}{ Catch after 6 months } \\
\hline $\begin{array}{l}\text { Number of immature } \\
\text { adults }\end{array}$ & 540 & 600 & 920 & 925 \\
\hline Number of juveniles & - & - & - & - \\
\hline $\begin{array}{l}\text { Total length (mm) of } \\
\text { adults (range) }\end{array}$ & $20-23$ & $20-24$ & $20-23$ & $20-22$ \\
\hline \multicolumn{5}{|l|}{ Catch after 9 months } \\
\hline Number of adults & 450 & 576 & 250 & 280 \\
\hline Number of juveniles & 750 & 960 & 410 & 400 \\
\hline Total & 1200 & 1536 & 660 & 680 \\
\hline Total lenath (mm) (range) & A $23-32$ & A $23-33$ & A $22-32$ & A $22-32$ \\
\hline IOtal IEngun (IIIII) (Iarige) & $\mathrm{J} 4-11$ & $\mathrm{~J} 4-12$ & $\mathrm{~J} 4-11$ & $\mathrm{~J} 4-12$ \\
\hline \multicolumn{5}{|l|}{ Catch after 12 months } \\
\hline Number of adults & 450 & 576 & 250 & 280 \\
\hline Number of juvenile & 2140 & 2840 & 1110 & 1300 \\
\hline Total & 2590 & 3416 & 1360 & 1580 \\
\hline Total length (mm) (range) & A 25-33 J+IM 4-16 & A $25-34 \mathrm{~J}+\mathrm{IM} 4-16$ & A $24-33 \mathrm{~J}+\mathrm{IM} 4-16$ & A $24-34$ J+IM 4-16 \\
\hline
\end{tabular}

Note: $B F=$ Berried female, $A=$ Adult (unsexed), $I M=$ Immature adult, J=Juvenile

\section{Discussion}

The production of shrimps viz., M. rosenbergii, Penaeus monodon and $M$. lamarrei in culture water has a direct relationship with the stocking density (Sandifer and Smith 1975, Allan and Maguire 1992, Singh and Qureshi 1997) and the average rate of individuals is negatively correlated with stocking rate (Willis and Berrigan 1977). Takata (1974) reported only $18 \%$ survivability of $M$. rosenbergii with a stocking density of $18 / \mathrm{m} 2$ over a 300 days of culture period. The author commented that the abrupt depletion of dissolved oxygen, disease and cannibalism were the major factors for such a low production. Ling (1969) reported 69\% of mortalities of $M$. rosenbergii stocked at a rate of $166 / \mathrm{m}^{2}$ resulted in cannibalistic behaviour of the stocked individuals. Similar results have also been reported by Humayun et al. (1986).

Shing and Qureshi (1997) reported that individual mean weight gain (\%) exhibited inverse relationship with the stocking densities in M. lamarrei lamarrei; Allan and Marguire (1992) observed similar result in Penaeus monodon. Sandifer and Smith (1977) and Willis and Berigan (1977) reported that survival is inversely proportional to the stocking densities in M. rosenbergii; which is also true for M. lamarrei (Singh and Qureshi 1997).

In the present study, it was found that $M$. lamarrei preferred sandy-muddy bottom, the population growth was below $50 \%$ in the cemented bottom tank. Soundarapandian et al. (1997) found very low survival (30.8\%) in the cement tank for larviculture of M. malcomsonii, which is supported by the report of Kannupandi (1995). 
Kannupandi (1995) and Soundarapandian et al. (1997) were in opinion that larval rearing of M. malcomsonii and $M$. rosenbergii is suitable in rectangular or round tanks with flat bottoms. They preferred fibre glass tanks than plastic or cemented tanks. However, the production rate of $M$. lamarrei would be increased if supplemental feed were provided, as cannibalism in post larval stage due to underfeeding rate as reported by Soundarapandian et al. (1997). In the present experiment vegetation were present in tanks, which may also played food and shelter for not only the prawns but also the other organisms present in the supplied pond water, which in turn met up the nutrition demand of the M. lamarrei larvae.

M. lamarrei was found to prefer spreading type of vegetation than the floating types. The population in the tank provided with Lemna and Wolffia was less than those were obtained in the tanks with Alternanthera or Ipomea. The reason might be that both Lemna and Wolffia covered the water surface allowing little sunlight to pass through. As a nature prawns avoid intense light. Ehsan et al. (1997) recorded low oxygen level where water hyacinth and aman paddy covered the water surface. When a mixed vegetation of both floating and spreading types was present, the yield of $M$. lamarrei was decreased. It might be due to the decreased penetration rate of sunlight, increased amount of dissolved carbon dioxide, oxygen depletion at night and presence of snails within the roots of the floating vegetation, which preyed on the larvae and juveniles of $M$. lamarrei.

\section{Conclusion}

The present findings would provide baseline information for establishing culture system for M. lamarrei and other smaller related species of this genus.

Acknowledgements: This work is a part of the PhD thesis of the first author, she is thankful to the Institute of Biological Sciences (IBSc), University of Rajshahi, for offering her fellowship. We are thankful to the IBSC and Department of Zoology, University of Rajshahi, for providing all the necessary laboratory facilities during this work.

\section{References}

Ali S, Chowdhury AN, Ray AR. 1980. Ecology and seasonal abundance of zooplankton in a pond in Tongi, Dacca .Bangladesh J Zool 8(1), 41-48.

Allan GL, Maguire GB. 1992. Effects of stocking density on production of Penaeus monodon Fabricus in model farming ponds. Aquaculture 107, 49-66. http://dx.doi:10.1016/0044-8486(92)90049-Q

Chaudhury PC. 1970. Complete larval development of the palaemonid shrimp Macrobrachium acanthurus (Weigmann 1836) reared in the laboratory. Crustaceana 18,113-132. http://dx.doi:10.1163/156854070X00743

Ehshan MA., Hossain MS, Mazid MA, Mollah MFA. Rahman S, Razzaque A. 1997. Limnology of Chanda beel. Bangladesh J Fish Res 11(1), 39-40.

Humayun NS, Alam AKN, Islam MA. 1986. Culture and production of Macrobrachium rosenbergii in a freshwater pond with Catla catla. Bangladesh J Fish 9 (1-2),1-7.

Kannupandi T. 1995. Development of technology for hatchery production in Macrobrachium malcolmsonii and M. rosenberdii $(\mathrm{H}$. M. Edwards) under pond conditions. Aquaculture 154, 79-85.

Kibria G. 1983. Bangladesher Chingri Sampad O Chingri Chas (Shrimp fishery and shrimp culture). Jahan Printing Press, Satkhira, Khulna, $126 \mathrm{pp}$.

Ling SW. 1969. The general biology and development of Macrobrachium rosenbergii (de Man). FAO Fish Rep 57, 589-606.

Parween S. 1982. Studies on some aspects of fisheries of freshwater prawns, Macrobrachium dayanum (Hend) of Rajshahi district. M. Phil. Thesis (unpublished). Department of Zoology, University of Rajshahi, $158 \mathrm{pp}$

Parween S, Dutta SK, Hossain MA. 1997. Post harvest management and utilization of SIS fishes including prawns. Proc. Seminar on Small Indigenous Specis (SIS) of Fish Culture in Bangladesh, IFADEP Sp-2,12 Dec.,1996, Rajshahi University. pp.141-146. 
Rajyalakshmi T. 1961. Larval development of Palaemon lamarrei (H.M.Eds.) and Leander fluminicola (Kemp). J Zool Soc India 13(3), 220-239.

Sandifer PA, Smith TIJ. 1975. Effects of population density on growth and survival of Macrobrachium rosenbergii reared in recirculating water. Proc World Mericul Soc 6,43-53. http://dx.doi:10.1111/j.1749-7345.1975.tb00006.x

Sandifer PA, Smith TIJ. 1977. Preliminary observations on a short claw growth form of the Malaysian Prawn, Macrobrachium rosenbergii (deMan). Proc. Nat. Shellfish. Assoc 67, 123-124.

Sing H, Qureshi TA. 1997. Production of freshwater prawn, Macrobrachium lamarrei lamarrei (H.M. Edwards 1837) at different stocking densities. Pakistan J Zool 29(2),101-105.

Soundarapandian P, Samuel MJ, Kanupandi TK. 1997. A simple method for the seed production of freshwater prawn Macrobrachium malcolmsonii (H. M. Edw.). J Aqua Trop 12, 261-266.

Takata M. 1974. Development of the prawn culture industry in Hawaii. NTIS scr. Com. 75-101-12, 26pp.

Tukey, J.W. 1953. The problem of multiple comparisons. Department of Statistics, Princeton University (Unpublished).

Wills SA. Berrigan ME. 1977. Effect of stock size and density on growth and survival of Macrobrachium rosenbergii in ponds. Proc World Mericul Soc 8, 251-258. http://dx.doi:10.1111/j.1749-7345.1977.tb00123.x 